\title{
High-precision U-Pb dating of complex zircon from the Lewisian Gneiss Complex of Scotland using an incremental CA-ID-TIMS approach
}

\author{
Q.G. Crowley ${ }^{\mathrm{a}, 1}$, R. Key ${ }^{\mathrm{b}}$, S.R. Noble ${ }^{\mathrm{c}}$ \\ a School of Natural Sciences, Department of Geology, Trinity College, Dublin 2, Ireland \\ b British Geological Survey, Murchison House, West Mains Road, Edinburgh EH9 3LA, UK \\ c NERC Isotope Geosciences Laboratory, British Geological Survey, Kingsley Dunham Centre, Keyworth, Nottingham NG12 5GG, UK
}

\section{A R T I C L E I N F O}

\section{Article history:}

Received 14 February 2014

Received in revised form 27 March 2014

Accepted 1 April 2014

Available online $\mathrm{xxxx}$

Handling Editor: M. Santosh

\section{Keywords:}

$\mathrm{U}-\mathrm{Pb}$ zircon geochronology

CA-TIMS

Precambrian

Lewisian Gneiss

\begin{abstract}
A B S T R A C T
A novel approach of thermally annealing and sequentially partially dissolving single zircon grains prior to highprecision Isotope Dilution Thermal Ionization Mass Spectrometry (ID-TIMS) is presented. This technique is applied to complex zircon from the Precambrian Lewisian Gneiss Complex of Scotland. Up to six partial dissolutions were conducted at incrementally higher temperatures and analysed at each successive step. ID-TIMS analyses reveal the portions of zircon affected by the lowest temperature partial dissolution step have suffered $\mathrm{Pb}-$ loss. Successively higher temperature partial dissolution steps yield a series of analyses from the younger domains, followed by mixing trajectories with older components, presumably from the inner domains. Specifically, for a partially retrogressed granulite tonalite gneiss from the central block (Assynt), high-grade metamorphic zircon ages of c. $2500 \mathrm{Ma}$ and c. $2700 \mathrm{Ma}$ are resolved with a protolith age of c. $2860 \mathrm{Ma}$ also recognised. This unequivocally demonstrates two separate episodes of high-grade metamorphism affected rocks from this region. The c. $2700 \mathrm{Ma}$ age provides a minimum age constraint on the highest pressure event known from Archean crustal rocks. Using this technique of pseudo-spatial resolution coupled with high-precision analysis it is possible to recognise discrete $\mathrm{Pb}$-loss and multiple stages of zircon growth or isotopic resetting within single grains to within $0.1-0.2 \%$ error $(2 \sigma)$ on individual ${ }^{207} \mathrm{~Pb} /{ }^{206} \mathrm{~Pb}$ ages. This method has relevance to U-Pb zircon geochronology where conventional micro-beam techniques are unable to resolve between separate ages within single grains.

(c) 2014 International Association for Gondwana Research. Published by Elsevier B.V. All rights reserved.
\end{abstract}

\section{Introduction}

The Lewisian Gneiss Complex, exposed for $140 \mathrm{~km}$ along the NW coast of Scotland and on the Outer Hebrides Islands, is one of the world's most intensively studied areas of Precambrian geology. It is composed of Archean gneisses which have been variably reworked during the Proterozoic and has proven to be a key region in the study of crustal growth and continental tectonics (e.g. Moorbath et al., 1969; Hamilton et al., 1979; Rollinson and Windley, 1980; Whitehouse and Moorbath, 1986; Heaman and Tarney, 1989; Coward, 1990; Whitehouse and Bridgwater, 2001; Rollinson, 2012; Johnson et al., 2013). The Lewisian gneisses, are predominantly tonalite-trondhjemite-granodiorite (TTG) gneisses but also feature gneisses of sedimentary origin, metamorphosed ultramafic rocks, mafic dykes and alkali granitoids, all of which are variably deformed and metamorphosed (Tarney and Weaver, 1987; Goodenough et al., 2013; MacDonald et al., 2013). Collectively these lithologies form part of a now-fragmented Precambrian terrane in the North Atlantic, which includes basement rocks in Scandinavia, Greenland and North America (e.g. Bergh et al., 2007; Borradaile and Geneviciene, 2008; Kolb et al., 2013). In addition to these areas, it is

E-mail address: crowleyq@tcd.ie (Q.G. Crowley).

${ }^{1}$ Tel.: + 35318962403 ; fax: + 35316711199 . thought that rocks of Lewisian affinity form unexposed basement over a large area of the North Atlantic region (Hitchen, 2004; Flowerdew et al., 2009; O'Driscoll et al., 2009; Cooper et al., 2011). Tectonothermal events, including formation of early granulites retrogressed during a later amphibolite facies event, recorded by the Lewisian gneisses are also found in many cratons worldwide (Bagas et al., 2013; Santosh et al., 2013; Jiang et al, 2013; Rekha et al., 2013; Verma and Verma, 2013) and appear to represent periods of significant crustal growth. Recent paleogeographic reconstructions have placed the North Atlantic Craton proximal to the Dharwar Craton of India in Paleoproterozoic times (Nilsson et al., 2013) and have linked Lewisian rocks to formation of the supercontinent Columbia (Baba, 2002; Goodenough et al., 2013). Understanding the geological evolution of the Lewisian Gneiss Complex exposed in NE Scotland therefore affects our understanding of a much broader geographic area and is pertinent to the study of global tectonic processes and crustal growth in Archean and Proterozoic times.

\section{Background}

\subsection{Regional geology}

The oldest protoliths of the Lewisian Gneiss Complex may span the Paleo-, Meso- and Neo-Archean (Corfu et al., 1998; Friend and Kinny, 
2001; Love et al., 2010; Goodenough et al., 2013). They have been variably affected by a Neo-Archean granulite event termed the Badcallian (Park, 1970) and two lower grade Paleoproterozoic events termed the Inverian (Evans, 1965) and Laxfordian (Sutton and Watson, 1950). The Inverian and Laxfordian events are separated by a phase of intrusion of mafic dykes, known as the Scourie dykes (Park, 1966). Uncertainties and controversy exist regarding the timing of these separate tectonomagmatic events, but they may be defined as (1) Badcallian at c. 2700 or c. 2490-2480 Ma, (2) Inverian at c. 2490-2480 Ma, (3) intrusion of Scourie dykes 2400-2000 Ma (Heaman and Tarney, 1989; Waters et al., 1990), early Laxfordian at c. 1900-1870 Ma and late Laxfordian at c. $1790-1770 \mathrm{Ma}$.

Structurally, the mainland Lewisian Gneiss Complex may be divided into northern (Rhiconich block), central (Assynt and Gruinard blocks) and southern (Loch Maree) regions separated by major shear zones which developed in the Inverian and were subsequently reworked in the Laxfordian (Fig. 1). Mainland tectonic blocks now situated north of
Gairloch are considered to have been assembled during the Inverian event (Goodenough et al., 2013). Lewisian gneisses exposed in the southern mainland block and on islands off the NW coast of Scotland feature Archean protoliths reworked during formation of Paleoproterozoic subduction and accretionary complexes (Friend and Kinny, 2001; Park et al., 2001; Mason and Brewer, 2005; Mason, 2012).

For the mainland Lewisian Gneiss Complex, the Rhiconich block is predominantly composed of migmatitic gneisses of amphibolite grade and of broadly granodioritic composition (Kinny and Friend, 1997; Goodenough et al., 2010). Protolith ages are in the range of 2840-2680 Ma with rare inherited ages of c. 3000 and 3550 Ma (Kinny and Friend, 1997; Friend and Kinny, 2001). The Rhiconich and Assynt blocks are separated by the Laxford Shear Zone (Evans, 1965; Corfu et al., 1994; Goodenough et al., 2010; 2013). The central region may be further subdivided into Assynt and Gruinard blocks, separated by the Canisp Shear Zone (Coward and Park, 1987; Chattopadhyay et al., 2010; Goodenough et al., 2010). The Assynt block features TTG gneisses

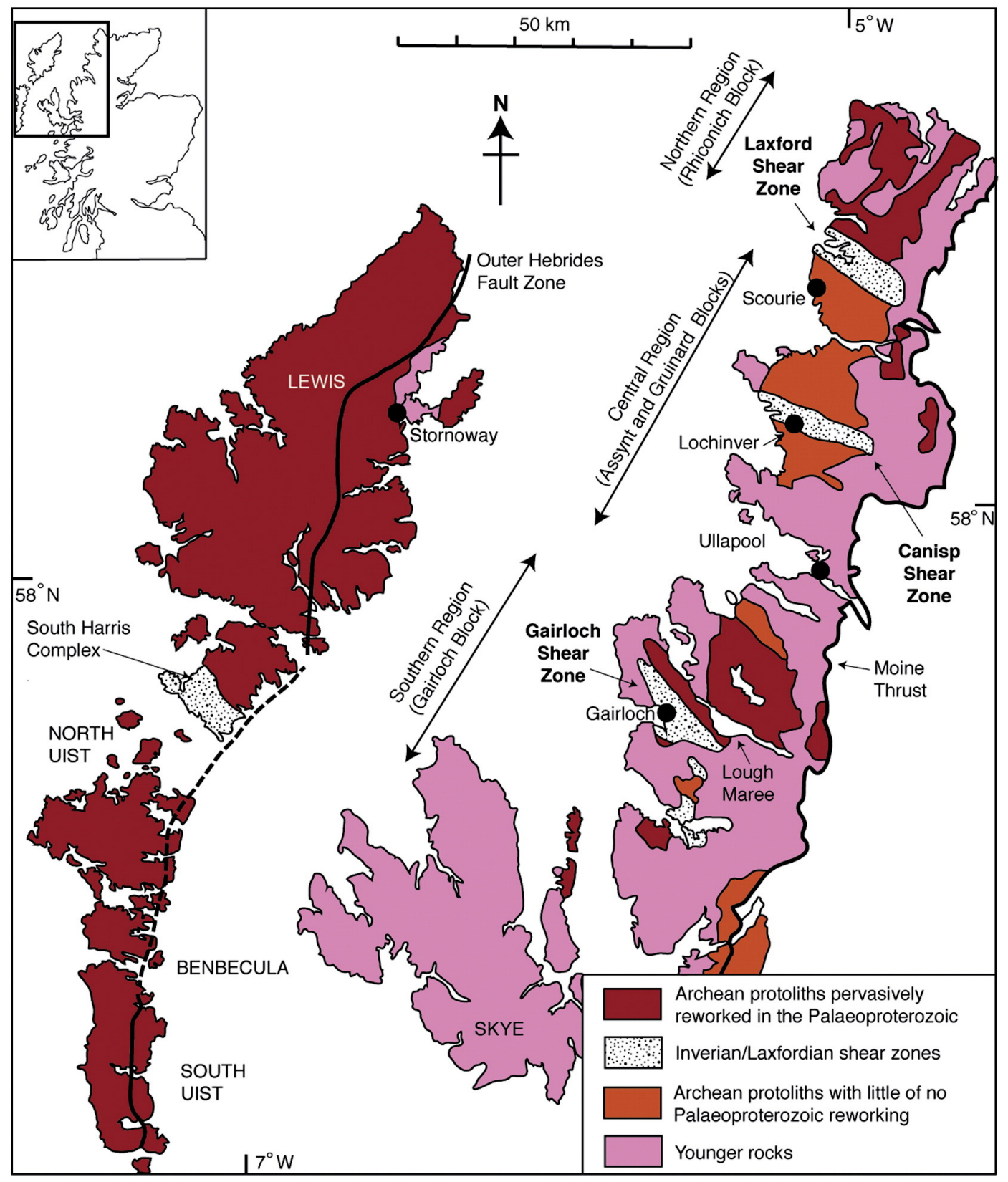

Fig. 1. Simplified geological map of the NW Scottish Highlands and Lewisian Gneiss Complex. Adapted from Goodenough et al. (2013). 
and metamorphosed mafic and ultramafic lithologies, some of which display granulite mineral assemblages formed during the Badcallian (Park, 1970). Granulite facies metamorphism has been estimated to have occurred at $1000-920{ }^{\circ} \mathrm{C}$ and $16-11$ kbar (O'Hara, 1977 ; Cartwright and Barnicoat, 1987; Sills and Rollinson, 1987; Zirkler et al., 2012). Recent work on relic eclogite assemblages found within maficultramafic rocks from the Assynt block has revised these estimates to 1060-1040 ${ }^{\circ} \mathrm{C}$ and $24-22$ kbar thus making these the highest known pressures recorded in Archean crustal rocks worldwide (Sajeev et al., 2013). The exact mode of formation of this high pressure (HP) metamorphism preserved within the Assynt block is unknown, but its presence signifies that deep lithospheric subduction and therefore some form of plate tectonics was active in the Archean. Timing of the eclogite event is not directly constrained and timing of the granulite event is disputed. Based on ion-probe $\mathrm{U}-\mathrm{Pb}$ dating of zircon it has been proposed that the granulites formed at c. 2490-2480 Ma (Love et al., 2010; Whitehouse and Kemp, 2010), but due to the inherent analytical uncertainty of the technique, an earlier c. 2760-2710 Ma event as previously suggested by others (Cohen et al., 1991; Corfu et al., 1994; Zhu et al., 1997) cannot be ruled out. Corfu et al. (1994) attributed a c. 2490-2480 Ma age from the Assynt block as having commenced with granulite metamorphism, but with local rehydration leading to partial melting and retrogression. Goodenough et al. (2013) interpreted this c. 2490-2480 Ma age as representing the amphibolite Inverian event with the inference that the granulite Badcallian event must be older than this, although this view is not universally accepted. Protolith ages from the Assynt block may be as old as 3030-2960 Ma (Kinny and Friend, 1997; Love et al., 2004), or alternatively may be substantially younger at c. 2850 Ma (Whitehouse and Kemp, 2010). This dispute on the protolith ages is centred on whether or not the oldest ages from these zircon represent inherited xenocrystic cores, or primary magmatic growth. For the Gruinard block, protolith ages of gneisses are considered to be c. 2860-2800 Ma (Corfu et al., 1998; Love et al., 2004) and granitoid rocks retrogressed from granulite facies have been constrained at c. $2730 \mathrm{Ma}$ (Corfu et al., 1998; Love et al., 2004). The Gruinard Shear Zone separates the Gruinard block from the southern region. The southern region contains tectonically reworked Lewisian Gneisses and the Loch Maree Group, the latter consists of supra-crustal rocks with both oceanic and continental components interpreted to represent a Paleoproterozoic accretionary complex (Park et al., 2001). This amalgamated with the Lewisian Gneiss Complex during Laxfordian events. From a global perspective, these magmatic events are considered to be linked with formation of the Columbia/Nuna supercontinent (Goodenough et al., 2013). Significant and widespread hydrothermal events affecting the Lewisian Gneiss Complex have been recorded at 1750 and $1670 \mathrm{Ma}$ (Corfu et al., 1994; Kinny and Friend, 1997; Kinny et al., 2005; Mason, 2012; Goodenough et al., 2013).

Although the Lewisian Gneiss Complex has been the subject of geological research for over a century, beginning with Peach et al. (1907), many aspects of its geological evolution remain controversial. Indeed, some of these outstanding controversies are likely a legacy of the long history of research in this area in that many isotope studies were undertaken when techniques were still in their infancy and have since either been improved upon or disregarded as obsolete (e.g. Giletti et al., 1961; Pidgeon and Aftalion, 1972). Among the key points still disputed are: (1) protolith ages of the gneisses, (2) age of granulite metamorphism in the Assynt block and (3) relative affinities of different fault bounded blocks. A key aspect of this study is to investigate the presence or absence of a ca 2760-2700 Ma event affecting the Assynt block and to evaluate if high-precision TIMS U-Pb zircon dating can reveal complexities not immediately obvious using conventional micro-beam dating techniques.

\subsection{Analytical challenges dating Lewisian gneisses}

The refractory nature of zircon means it often records and preserves relic age signatures, even when the original zircon has been subjected to burial deep in the Earth's crust and has experienced extreme metamorphic conditions. Although such information is useful for re-constructing geological histories of complex terranes, age determinations on zircon displaying multi-age domains are not without their analytical challenges. Zircon from the Lewisian Gneiss Complex often display extremely complex zonation in CL images (e.g. Corfu et al., 1998; Goodenough et al., 2013). Thermal Ionization Mass Spectrometry (TIMS) analyses of complex zircon, although precise, are often discordant and rely on calculation of upper and lower intercepts to estimate $\mathrm{U}-\mathrm{Pb}$ ages from different components. The precision of such intercept age calculations depends on the statistical fit of data to a discordia line and also how close the individual analyses plot to the intercept age. Where more than two age components are present, either in single or bulk grain fractions, it is typically difficult to interpret the resultant discordant arrays. For these reasons, micro-beam techniques, such as laser ablation inductively coupled plasma mass spectrometry (LA-ICP-MS) and ion probe (e.g. SIMS) are generally chosen over TIMS when dealing with zircon exhibiting multi-age domains. These latter techniques are relatively rapid compared with TIMS and, importantly, give a high spatial resolution. Ion probe spots typically have a $20 \mu \mathrm{m}$ (diameter) $\times 2-3 \mu \mathrm{m}$ (depth) geometry and utilise significantly less volume compared with conventional LA-ICP-MS techniques (typically 25-50 $\mu$ m diameter $\times$ $15-25 \mu \mathrm{m}$ depth). Although both micro-beam methods are capable of producing spot diameters smaller than $20 \mu \mathrm{m}$, a reduction in signal intensity often results in poor counting statistics and diminished analytical precision. Even with the advent of multi-ion counting instruments, which have seen an improvement of counting statistics for low intensity signals, standard-sample matrix effects generally limit accuracy to c. $1 \%$. For micro-beam techniques, individual spot analyses are usually guided by reference to BSEM or CL images of zircon interiors revealed in polished grains. In this way individual $\mathrm{U}-\mathrm{Pb}$ or $\mathrm{Pb}-\mathrm{Pb}$ ages, which generally have errors in the $1-2 \%$ range, can be related to particular zircon domains. Difficulty may arise if zircon age domains are $<20 \mu \mathrm{m}$ wide, as this may lead to sampling of more than one age domain and produce a discordant $\mathrm{U}-\mathrm{Pb}$ analysis. Furthermore, if the analysis is within error of U-Pb concordia, it may not be possible to distinguish a true concordant age from an apparent age produced by mixing of two different components, or to recognise minor $\mathrm{Pb}$-loss. Ion microprobe $\mathrm{U}-\mathrm{Pb}$ zircon data from Lewisian gneisses thought to have experienced high grade metamorphism often display a complex distribution along concordia. Such apparent age distributions are difficult to interpret and do not have a unique solution. Whitehouse and Kemp (2010) discussed the predicament of attempting to unravel the complexities of these zircon ages using an ion-probe by stating that analytical errors typically associated with the technique "preclude recognition of true concordance with a precision necessary to decipher an original magmatic age lying on concordia from one which has suffered later Pb-loss within just a few hundred Ma".

To summarise, it is difficult to further our understanding of evolution of the Lewisian Gneiss Complex, and some aspects of global Archean and Proterozoic tectonic processes, using conventional TIMS or microbeam dating methods. A technique integrating some form of spatial resolution with the high analytical precision of TIMS may help to solve some outstanding issues for this enigmatic and classic area of geology.

\subsection{Historical developments in TIMS dating of complex zircon}

Conventional ID-TIMS typically involves dissolving a high U, low initial $\mathrm{Pb}$ mineral (e.g. zircon) in high purity acids, equilibration with a $\mathrm{U}-\mathrm{Pb}$ isotope tracer, and analysis by TIMS. Pre-mass spectrometry steps may include application of physical or chemical treatments to eliminate $\mathrm{Pb}$-loss and ion exchange chemistry to purify $\mathrm{U}$ and $\mathrm{Pb}$ from matrix elements. As this analytical method is destructive and consumes part or all of a grain, a number of analytical strategies have been devised over time to permit the dating of complex grains. In some cases individual domains of distinct age can be physically 
separated and analysed separately, e.g. breaking off zircon rims from cores during mineral picking, but not all zircons are amenable to such treatment. Hence there have been numerous attempts to use a multistep partial dissolution combined with ID-TIMS to date complex zircon with more than a single age domain. In an early application of partial dissolution, Todt and Büsch (1981) were able to resolve paragneiss zircons into a c. 2000 Ma inherited component and zircon domains of probable metamorphic origin at $524 \pm 20 \mathrm{Ma}$. These ages were defined by upper and lower intercepts from a discordant array of U-Pb multigrain zircon data. The same study attempted to resolve the magmatic age of an orthogneiss by subjecting a large $31 \mathrm{mg}$ multi-grain zircon fraction to partial dissolution, with the final step dissolving all residual zircon. The first partial dissolution step had the highest concentration of $\mathrm{U}$ and gave an apparent ${ }^{207} \mathrm{~Pb} /{ }^{206} \mathrm{~Pb}$ age of $517 \pm 15 \mathrm{Ma}$, overlapping within error with the lower-intercept age determined from the paragneiss. Successive longer durations of partial dissolutions gave older ${ }^{207} \mathrm{~Pb} /{ }^{206} \mathrm{~Pb}$ apparent ages between 670 and $950 \mathrm{Ma}$. Todt and Büsch (1981) interpreted their data to show a high-U igneous overgrowth on older xenocrystic zircon. Scatter in the resulting data prevented determination of the age of the older component present in zircon from the orthogneiss, other than that it was $>950 \mathrm{Ma}$. Additionally, some of the analyses plotted reversely discordant due to some artefact of the partial dissolution processes. Subsequent to this study, Mattinson (1994) performed multi-step partial dissolution of complex zircon known to display Pb-loss and inheritance. In this case, a prolonged and several low temperature partial dissolution steps were followed by complete dissolution and TIMS analysis. Where zircon had no inheritance the resulting analyses were precise and concordant, whereas when xenocrysts were present the final analyses were discordant. McClelland and Mattinson (1996) applied a similar technique to bulk zircon fractions $(0.1-8.3 \mathrm{mg}$ ) in order to remove or isolate the effects of older xenocrystic components or secondary Pb-loss. An initial low temperature leaching was followed by high temperature steps. Final residues, which were visually estimated to be c. $10 \%$ of the original zircon mass, were then dissolved. McClelland and Mattinson (1996) showed that the partial dissolution steps removed both outer layers which were susceptible to Pb-loss, as well as inner cores which contained the older inherited components. It was observed that final residues often displayed "hollow shells of low-U primary igneous zircon". Dissolution and TIMS analysis of these final residues yielded reproducible and concordant ages interpreted as representing magmatic ages without any effect from inheritance or Pb-loss. It was deduced that the multi-step approach had not introduced any artificial fractionation of $\mathrm{Pb}$ and $\mathrm{U}$ isotopes. Mattinson et al. (1996) however later observed that such multi-step procedures can indeed introduce fractionation of $\mathrm{Pb}$ and $U$ isotopes. In such cases, the analysed fractions contained not only $\mathrm{Pb}$ and $\mathrm{U}$ from the dissolved fraction, but additional radiogenic $\mathrm{Pb}$ and intermediate daughter products, such as ${ }^{234} \mathrm{U}$, interpreted as having been leached from residual zircon. Earlier leachates were found to be more enriched in ${ }^{234} \mathrm{U}$ and unsupported radiogenic $\mathrm{Pb}$ (more ${ }^{206} \mathrm{~Pb}$ than ${ }^{207} \mathrm{~Pb}$ ), possibly because these occupied alpha-recoil damage sites and had been displaced to micro-cracks and fission tracks. Further insights into the effects of partial dissolution were gained by the experiments of Corfu (2000), who subjected Archean zircon to a three step dissolution process. Room temperature acid treatment of the zircons resulted in young ${ }^{207} \mathrm{~Pb} /{ }^{206} \mathrm{~Pb}$ ages in the leachates. The second dissolution step was performed in a scaled-down version of a Krogh-type dissolution capsule (Krogh, 1973) at $190^{\circ} \mathrm{C}$ which liberated "excessively old" radiogenic $\mathrm{Pb}$, whereas the third and final step fully dissolved the remaining zircon and produced ages consistent with conventional air abrasion-dissolution techniques. Corfu (2000) concluded that the excessively old ages resulted from "segregation of $\mathrm{Pb}$ in zircon sub-domains during [natural] thermal annealing episodes early in its history".

Following on from these earlier multi-step dissolution approaches, Mattinson (2005) developed a technique to thermally anneal zircon lattice radiation damage at temperatures between 800 and $1100{ }^{\circ} \mathrm{C}$ for $50 \mathrm{~h}$ prior to partial dissolution steps. This "chemical abrasion TIMS" (CA-TIMS) was specifically developed to remove the effects of Pb-loss prior to TIMS analysis. Whereas air-abrasion (Krogh, 1982) mechanically removes the outer portions of zircon, thermal annealing followed by partial dissolution (i.e. CA) preferentially removes high-U domains from zircon, even if these domains are not at the grain exterior. High$\mathrm{U}$ domains are likely to have suffered proportionally more alpha-recoil radiation damage, and in this way the CA technique effectively removes portions of zircon affected by Pb-loss. Several studies have demonstrated an improved accuracy when zircon are treated by CA, producing slightly but significantly older $\mathrm{U}-\mathrm{Pb}$ ages than when air-abraded (e.g. Mundil et al., 2004). The CA technique has also been effectively adapted for use in SIMS U-Pb zircon geochronology (Kryza et al., 2012). The CATIMS of Mattinson (2005) has now been widely adopted by the U-Pb geochronology community and is generally used in preference to the pioneering air-abrasion technique developed by Krogh (1982), becoming a critical component of modern high-precision $\mathrm{U}-\mathrm{Pb}$ zircon geochronology.

\section{CA-TIMS with step-wise dissolution}

In order to address some of the issues that can complicate both microbeam and older air abrasion TIMS geochronology of complex highgrade metamorphic terranes, such as in the Lewisian, it is proposed that combining a Mattinson (2005) CA-TIMS approach with sequential dissolution can yield useful insights on the true protolith age and timing of metamorphism in these difficult rocks. Our aim was to exploit the ability of high-temperature annealing to reduce zircon susceptibility to decoupling of $\mathrm{U}$ and $\mathrm{Pb}$ from areas suffering varying degrees of alpha-recoil damage and then to use partial dissolution steps, rather than the more conventional single high temperature dissolution step, to map out different degrees of zircon discordance. Following the monitored progressive removal of the bulk of zircon affected by Pbloss, subsequent dissolution steps were employed to attempt analysis of structurally \pm temporally differing zircon domains by exploiting small differences of high temperature acid solubility. As these resultant concordant data might reflect differing proportions of primary and metamorphic zircon, there was the potential for generating data arrays along concordia that could then be interpreted without the complication of the additional "noise" of superimposed Pb-loss, as highlighted in Whitehouse and Kemp (2010).

\subsection{Materials and methods}

All analytical work was performed at the NERC Isotope Geosciences Laboratory (NIGL) at the British Geological Survey. Approximately $12 \mathrm{~kg}$ of a Lewisian tonalitic granulite gneiss (LG-02) was collected from the Assynt block on the mainland of NW Scotland (grid reference NC 05864 24227), north of Lochinver and on the northern margins of the Canisp Shear Zone (Figs. 1 and 2). The sample was crushed and zircon separated by standard techniques (Rogers table, Frantz LB-1 magnetic separation, and heavy-liquid separation using methylene iodide). Representative zircons were handpicked in alcohol under a binocular microscope. A bulk zircon fraction of these selected zircons (c. >100 grains) was thermally annealed at $800{ }^{\circ} \mathrm{C}$ in a quartz glass beaker in a muffle furnace for $60 \mathrm{~h}$. After cooling, the surface contamination on zircon crystals was removed using $4 \mathrm{~N} \mathrm{HNO}_{3}$, followed by rinsing in ultrapure water (Milli-Q $18 \mathrm{M} \Omega$ ). The annealed and cleaned zircon fraction was separated into single grains or single grain fragments. These were pipetted into PFA 1.5 ml Savillex ${ }^{\mathrm{TM}}$ micro-centrifuge tubes modified by cutting $1 \mathrm{~mm}$ wide channels in the rim and lid to allow for vapour exchange at high temperatures. High purity $29 \mathrm{~N} \mathrm{HF}(200 \mu \mathrm{l}), 8 \mathrm{~N} \mathrm{HNO}_{3}$ $(20 \mu \mathrm{l})$ and $\mathrm{a}^{205} \mathrm{~Pb}-{ }^{235} \mathrm{U}$ isotope tracer solution were added to each micro-centrifuge tube, which were placed in a specially made PFA rack in a $125 \mathrm{ml}$ Parr ${ }^{\mathrm{TM}}$ bomb. Single zircon grains or grain fragments 

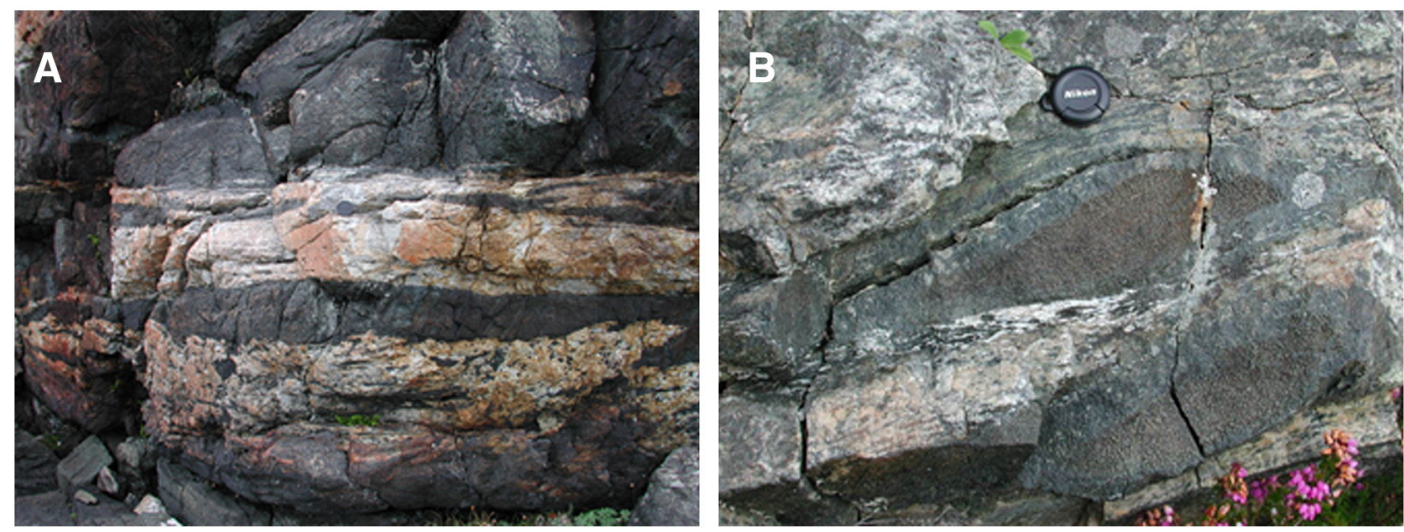

Fig. 2. Field photographs of Lewisian gneisses showing (A) relationship of tonalite gneiss with other gneiss types, (B) deformed lenses of ultra-mafic gneisses.

were treated with up to six 12 hour partial dissolution steps at 150,170 , 190,200 and $210{ }^{\circ} \mathrm{C}$ with the final residue fully dissolved at $240{ }^{\circ} \mathrm{C}$ for $48 \mathrm{~h}$. The solutions from the lowest temperature step were discarded and all others were spiked, equilibrated, and analysed by TIMS. After each partial dissolution step, the $\mathrm{HF}-\mathrm{HNO}_{3}$ containing the partially dissolved fraction and isotope tracer was removed, the residual zircon grain was rinsed in super pure water, and then cleaned in $3 \mathrm{~N} \mathrm{HCl}$ on a hotplate at $60{ }^{\circ} \mathrm{C}$ for $4 \mathrm{~h}$. The purpose of this step is to remove all $\mathrm{U}$ and $\mathrm{Pb}$ liberated by dissolution and that may have precipitated or adsorbed on the residual grain surfaces. After cleaning, the $3 \mathrm{~N} \mathrm{HCl}$ was removed and the single grain fractions were rinsed in super pure water ready for the subsequent partial dissolution, or final complete dissolution step. $10 \mu \mathrm{l}$ of $0.02 \mathrm{M} \mathrm{H}_{3} \mathrm{PO}_{4}$ was added to the $\mathrm{HF}-\mathrm{HNO}_{3}$ solution containing the partially dissolved zircon fraction and dried down in Savillex ${ }^{\mathrm{TM}}$ PFA beakers on a hotplate at $180{ }^{\circ} \mathrm{C}$. This was taken up in $50 \mu \mathrm{l}$ of $6 \mathrm{~N} \mathrm{HCl}$, dried down and repeated to ensure complete conversion to chloride. Solutions from the final dissolution step were also converted to chloride, but with one $6 \mathrm{~N}$ and one $3.1 \mathrm{~N} \mathrm{HCl}$ conversion step. Only solutions from the final dissolution step were loaded onto $50 \mu \mathrm{l}$ resin capacity PTFE ion exchange columns containing AG-1 X8 (200-400 mesh) resin to separate the $\mathrm{Pb}$ and $\mathrm{U}$ from concomitant $\mathrm{Zr}$, Hf, REE and Y following Krogh (1973) with modifications (Corfu and Noble, 1992). Each dried down sample fraction was loaded onto a degassed zone refined Re filament in silica gel. The gel was made following the method of Gerstenberger and Haase (1997) with some modifications. This was prepared by adding $20 \mathrm{~g}$ of colloidal silicic acid (Merck) to a solution of $0.8 \mathrm{~g}$ of $85 \% \mathrm{H}_{3} \mathrm{PO}_{4}$ (Merck suprapure) in $195 \mathrm{~g}$ of $1 \mathrm{~N} \mathrm{HBr}$. The $1 \mathrm{~N} \mathrm{HBr}$ was first purified by passing through $10 \mathrm{ml}$ capacity Biorad Econopac ${ }^{\mathrm{TM}}$ columns with anion-exchange resin AG-1X8 (200-400 mesh). The resulting silica gel was subsequently passed through a column containing AG-1X8 (50-100 mesh) to further lower its $\mathrm{Pb}$ content. $1 \mu \mathrm{l}$ of the resultant silica gel colloidal suspension prepared in this way was loaded onto degassed zone-refined Re filaments and gave $\mathrm{Pb}$ loading blanks of $20 \mathrm{fg}$ and $>5 \% \mathrm{~Pb}$ ionization efficiency at ionization temperatures of $1410-1450{ }^{\circ} \mathrm{C}$ for $\mathrm{Pb}$, and $\mathrm{U}$ ionization at $1500-1550{ }^{\circ} \mathrm{C}$. These relatively high ionization temperatures, as compared with silica gels prepared conventionally (Gerstenberger and Haase, 1997) resulted in effective elimination of organic residue prior to data acquisition. $5 \mu \mathrm{l}$ of silica gel was used for all but the final zircon fractions, where only $1 \mu \mathrm{l}$ was used. The larger volume of silica gel used for the partial dissolution fractions was to compensate for any loss in ionization efficiency due to these fractions not being passed through ion-exchange columns. ID-TIMS analysis of samples was performed directly after conversion of each partial dissolution step to chloride, so that the completeness of dissolution of individual age domains could be assessed prior to the next phase of partial dissolution of the zircon grains. Individual partial dissolution and ID-TIMS analysis for five separate single zircon grains were performed in a $24 \mathrm{~h}$ period. All ID-TIMS data reported here were acquired in a six day period.

Total procedural blanks, which were treated in an identical manner to the samples, gave $0.1-0.2 \mathrm{pg} \mathrm{Pb}$ and $0.08-0.1 \mathrm{pg}$ U. Samples were blank-corrected using the measured blank ${ }^{204} \mathrm{~Pb}:{ }^{206} \mathrm{~Pb}:{ }^{207} \mathrm{~Pb}:{ }^{208} \mathrm{~Pb}$ ratio of 1:18.19:15:58:38.50. Correction for residual common lead above analytical blank was carried out using the Stacey-Kramers common lead evolutionary model (Stacey and Kramers, 1975).

A representative population of annealed zircon was subjected to partial dissolution at $180{ }^{\circ} \mathrm{C}$, mounted in epoxy resin in a grain mount, ground and polished to their equatorial cross-sections (final polish step with $0.5 \mu \mathrm{m}$ diamond paste) and imaged with a secondary electron microscope using cathodoluminescence $(\mathrm{CL})$. This was done in order to examine the internal structures preserved within zircon after annealing and the first, lowest temperature, partial dissolution step to aid with interpretation of $\mathrm{U}-\mathrm{Pb}$ and $\mathrm{Pb}-\mathrm{Pb}$ data from this study (Fig. 3).

\subsection{Instrumentation}

A Thermo Electron Triton TIMS instrument equipped with a Mascom secondary electron multiplier (SEM) was used to analyse $\mathrm{Pb}$ and $\mathrm{U}$ isotope compositions. This new generation of SEM was characterised by Noble et al. (2006) over a range of beam intensities from 50 to $>1.3 \mathrm{M}$ counts per second (cps). Work with Thermo and Mascom resulted in an SEM with several fundamental differences to typical TIMS SEM devices: superior peak shape through modified first dynode geometry, improved linearity and stability facilitated by lower operating voltage and reduced number of dynodes, and modifications to post-SEM electronics. Linearity, gain, Faraday/SEM bias and hysteresis were characterised using Sr (SRM 987) and U (SRM U500) during installation and at regular intervals. In addition to this, SEM accuracy and precision for $\mathrm{Pb}$ was achieved by daily monitoring of SRM 981 and 982 . Linearity was better than $0.1 \%$ from 0.1 to $1 \mathrm{M}$ cps, requiring only a species specific deadtime correction. Hysteresis of $0.1 \%$ of previous signal during peak jumping of $\sim 1.5 \mathrm{~s}$ at $>300 \mathrm{k}$ cps was measured early in the detector life but subsequently decreased to negligible levels. A precautionary two second settling time was applied during peak-jumping routines. Long term (c. two years of daily use) performance monitoring using SRM 981 and $982 \mathrm{~Pb}$ indicates external reproducibility of data internally normalised to ${ }^{207} \mathrm{~Pb} /{ }^{206} \mathrm{~Pb}$ of c. $\leq 0.1 \%(2 \sigma)$ and an SEM mass bias relative to Faraday measurements of $0.16 \pm .05 \%$ per amu.

Dynamic peak jumping routines were used for both $\mathrm{Pb}$ and $\mathrm{U}$ data acquisition. A minimum of 100 ratios were collected for $\mathrm{Pb}$ and 60 for $\mathrm{U}$. $\mathrm{Pb}$ ratios were scrutinised for evidence of organic interferences, which were determined to be negligible. $\mathrm{A} \mathrm{Ba}_{3}\left(\mathrm{PO}_{4}\right)_{2}$ molecular interference on ${ }^{203} \mathrm{Tl}$ was measured in order to permit accurate isobaric interference corrections for ${ }^{205} \mathrm{Tl}$ on ${ }^{205} \mathrm{~Pb}$. Uncertainties were calculated using numerical error propagation (Ludwig, 1980). Isotope ratios were 

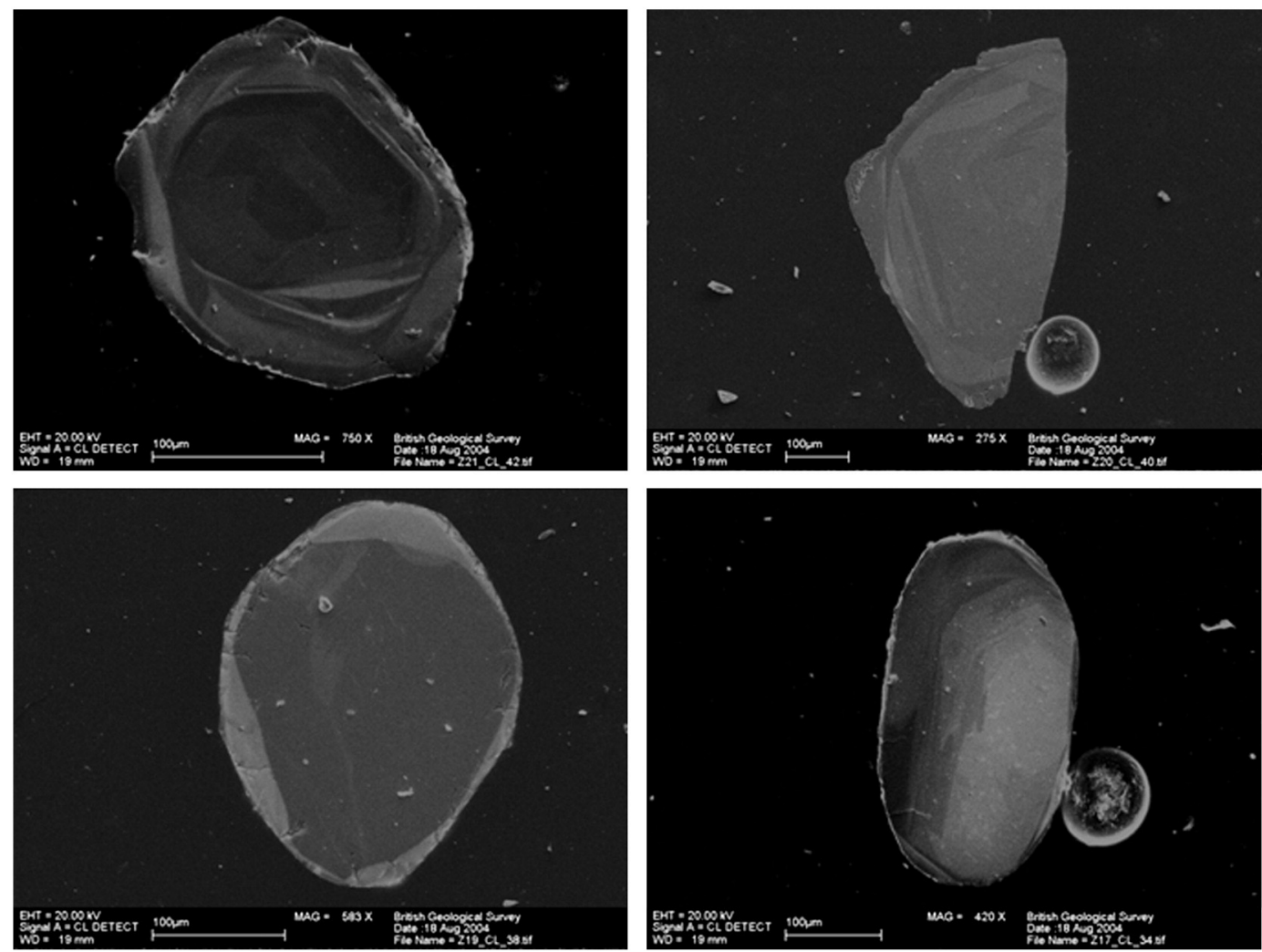

Fig. 3. Representative CL images of zircons from a tonalite gneiss of the central (Assynt) block.

plotted using Isoplot version 3; error ellipses reflect $2 \sigma$ uncertainty. These data were acquired prior to the EarthTime ${ }^{205} \mathrm{~Pb}-{ }^{23} \mathrm{U}-{ }^{235} \mathrm{U}$ tracer becoming available. Uncertainties on the ${ }^{205} \mathrm{~Pb}-{ }^{235} \mathrm{U}$ tracer employed in this study were conservatively estimated at $0.1 \%$.

\section{Results}

Representative CL images of zircon (Fig. 3) show complex zonation patterns in which it is sometimes possible to recognise one or more metamorphic domains (outer) with occasional oscillatory zoned zircon cores. Note that some zircon grains do not appear to show any oscillatory zoning and either represent zircon formed at high-grade metamorphic conditions or the effects of these high-grade conditions on earlier formed igneous zircon. Full analytical results are presented in Table 1 and plotted on the U-Pb concordia diagrams (Figs. 4 and 5). All ages reported are ${ }^{207} \mathrm{~Pb} /{ }^{206} \mathrm{~Pb}$ ages, unless otherwise stated. Errors are reported at $2 \sigma$ and include tracer calibration and decay constant uncertainties. All grains, with the exception of Z1 are large (c. $200 \times$ $250 \times 300 \mu \mathrm{m})$ multi-faceted zircons. The process of thermally annealing grains was observed to propagate weaknesses along internal grain boundaries which occasionally resulted in dislocation of different structural domains. A general outcome of this step-wise CA-TIMS approach was observed to be a reduction in Pb-loss, compared with some previously published non-CA TIMS analyses from similar samples of Lewisian Gneiss zircon (e.g. Corfu et al., 1998). Secondly, it was observed that subsequent higher temperature partial dissolutions tended to yield progressively older ages or older apparent ages. The results are now described in detail for each of the zircon fractions analysed.

Zircon fraction $\mathrm{Z} 1$ is a fragment of an outer growth zone which was handpicked from a larger grain. The first $\left(170^{\circ} \mathrm{C}\right)$ partial dissolution yielded $5 \mathrm{pg}$ of radiogenic $\mathrm{Pb}$ and a $1.4 \%$ discordant analysis with an age of $2512 \pm 3 \mathrm{Ma}$ (Fig. 4A). The subsequent four partial dissolutions $\left(190,200\right.$ and $\left.210{ }^{\circ} \mathrm{C}\right)$ yielded c. 14,52 , and $30 \mathrm{pg}$ of radiogenic $\mathrm{Pb}$ respectively. These three analyses give a weighted mean age of
$2505 \pm 6 \mathrm{Ma}$, but with a range beyond analytical error, thus indicating the presence of some older zircon. The youngest concordant date of $2502 \pm 2 \mathrm{Ma}$ is taken as the maximum age of this event. This is the age of the outermost rim from this zircon, which is interpreted as metamorphic in origin based on CL images of zircons from this sample.

The first partial dissolution $\left(170^{\circ} \mathrm{C}\right)$ from zircon $Z 2$ liberated $9 \mathrm{pg}$ of radiogenic $\mathrm{Pb}$ and yielded a $2 \%$ discordant analysis with an age of $2576 \pm 2 \mathrm{Ma}$. Each of the five following partial dissolution steps (190, $190,200,210$ and $210{ }^{\circ} \mathrm{C}$ ) yielded analyses with decreasing discordance (0.9-0.2\%) and successively older $\mathrm{U}-\mathrm{Pb}$ apparent ages (Fig. 4B). The age from the full dissolution $\left(240{ }^{\circ} \mathrm{C}\right)$ of zircon $\mathrm{Z} 2$ is $2711 \pm 3 \mathrm{Ma}$, but this lies off the trajectory of other analyses so likely signifies an older component not present in the lower temperature partial dissolutions. Disregarding the first and final analyses yields a statistically valid discordia array with an upper intercept of $2687 \pm 14 \mathrm{Ma}$ (MSWD $=$ 0.26). The lower intercept age has a large error and may not have any real significance. Given the younger metamorphic rim age of $c$. $2500 \mathrm{Ma}$ determined for $\mathrm{Z} 1$ and the prevalence of large metamorphic domains observed in CL from most of the zircons in this sample, this age of $2687 \pm 14 \mathrm{Ma}$ is interpreted as representing an earlier metamorphic episode.

The first two partial dissolution steps $\left(170\right.$ and $190{ }^{\circ} \mathrm{C}$ ) for $\mathrm{Z3}$ give slightly discordant analyses (1.6 and 1.0\%) with 27 and 70 pg of radiogenic $\mathrm{Pb}$ respectively and $\mathrm{Pb}-\mathrm{Pb}$ ages of c. $2510 \mathrm{Ma}$ (Fig. 4C). Subsequent partial dissolutions $\left(190,200\right.$ and $210^{\circ} \mathrm{C}$ ) give increasing older and less discordant apparent ages, with Z3-5 defining a concordant analysis at $2706 \pm 2 \mathrm{Ma}$ from $167 \mathrm{pg}{ }^{*} \mathrm{~Pb}$. Complete dissolution of the residual fraction yields an analysis overlapping with concordia at c. $2743 \pm 1 \mathrm{Ma}$. These data are interpreted as representing (1) Pb-loss from the first two analyses dominated by a c. 2500 Ma metamorphic component, but including a minor older component, (2) mixtures of c. 2500 and 2700 Ma metamorphic components and (3) mixtures between c. $2700 \mathrm{Ma}$ and a minor older component with the latter being either being magmatic or inherited in origin. 
Table 1

ID-TIMS zircon data.

\begin{tabular}{|c|c|c|c|c|c|c|c|c|c|c|c|c|c|c|c|c|c|c|c|c|}
\hline Zircon fraction & $\begin{array}{l}\mathrm{CA} \\
\left({ }^{\circ} \mathrm{C}\right)\end{array}$ & $\begin{array}{l}\mathrm{U} \\
(\mathrm{pg})\end{array}$ & $\begin{array}{l}\mathrm{Pb} \\
(\mathrm{pg})\end{array}$ & $\begin{array}{l}\mathrm{Cm} \mathrm{Pb} \\
(\mathrm{pg})\end{array}$ & ${ }^{206} \mathrm{~Pb} /{ }^{204} \mathrm{pb}^{\mathrm{a}}$ & ${ }^{208} \mathrm{~Pb} /{ }^{206} \mathrm{~Pb}^{\mathrm{b}}$ & ${ }^{206} \mathrm{~Pb}^{238} \mathrm{U}^{\mathrm{b}}$ & $\begin{array}{l}\% \text { err } \\
(2 \delta)\end{array}$ & ${ }^{207} \mathrm{~Pb} /{ }^{235} \mathrm{U}^{\mathrm{b}}$ & $\begin{array}{l}\text { \% err } \\
(2 \delta)\end{array}$ & ${ }^{207} \mathrm{~Pb} /{ }^{206} \mathrm{~Pb}^{\mathrm{b}}$ & $\begin{array}{l}\% \text { err } \\
(2 \delta)\end{array}$ & $\mathrm{Rho}^{\mathrm{c}}$ & $\begin{array}{l}{ }^{206} \mathrm{~Pb}^{238} \mathrm{U} \\
\text { Age }\end{array}$ & $\begin{array}{l}\text { Abs err } \\
(2 \delta)\end{array}$ & $\begin{array}{l}{ }^{207} \mathrm{~Pb} /{ }^{235} \mathrm{U} \\
\text { Age }\end{array}$ & $\begin{array}{l}\text { Abs err } \\
(2 \delta)\end{array}$ & $\begin{array}{l}{ }^{207} \mathrm{~Pb} /{ }^{206} \mathrm{~Pb} \\
\mathrm{Age}\end{array}$ & $\begin{array}{l}\text { Abs err } \\
(2 \delta)\end{array}$ & \% Disc \\
\hline Z1-1 & 170 & 2 & 5 & 0.2 & 1348 & 0.13853 & 0.46862 & 0.52 & 10.6929 & 0.53 & 0.16549 & 0.16 & 0.95 & 2477.50 & 12.90 & 2496.81 & 13.34 & 2512.54 & 4.06 & 1.4 \\
\hline $\mathrm{Z1-2}$ & 190 & 25 & 14 & 0.3 & 2284 & 0.13742 & 0.47422 & 0.28 & 10.7540 & 0.29 & 0.16447 & 0.09 & 0.95 & 2502.05 & 7.01 & 2502.10 & 7.29 & 2502.14 & 2.24 & 0.0 \\
\hline Z1-4 & 200 & 97 & 52 & 0.3 & 8736 & 0.14776 & 0.47473 & 0.20 & 10.7805 & 0.21 & 0.16470 & 0.08 & 0.93 & 2504.28 & 4.93 & 2504.39 & 5.31 & 2504.48 & 1.99 & 0.0 \\
\hline Z1-5 & 210 & 146 & 81 & 2.1 & 1801 & 0.14915 & 0.47594 & 0.77 & 10.8309 & 0.77 & 0.16505 & 0.07 & 1.00 & 2509.54 & 19.24 & 2508.72 & 19.31 & 2508.06 & 1.65 & -0.1 \\
\hline Z1-6 & 210 & 55 & 30 & 0.2 & 6423 & 0.14480 & 0.47467 & 0.20 & 10.7940 & 0.22 & 0.16493 & 0.08 & 0.93 & 2503.99 & 5.13 & 2505.55 & 5.49 & 2506.82 & 2.01 & 0.1 \\
\hline Z2-1 & 170 & 18 & 9 & 0.2 & 1959 & 0.10826 & 0.47884 & 0.35 & 11.3445 & 0.36 & 0.17183 & 0.11 & 0.96 & 2522.22 & 8.79 & 2551.87 & 9.17 & 2575.52 & 2.71 & 2.1 \\
\hline Z2-2 & 190 & 28 & 16 & 0.1 & 6175 & 0.12544 & 0.49211 & 0.25 & 11.8529 & 0.25 & 0.17469 & 0.07 & 0.96 & 2579.79 & 6.34 & 2592.85 & 6.58 & 2603.07 & 1.89 & 0.9 \\
\hline Z2-3 & 190 & 44 & 25 & 0.2 & 5958 & 0.15053 & 0.49712 & 0.58 & 12.0902 & 0.59 & 0.17639 & 0.08 & 0.99 & 2601.39 & 15.21 & 2611.43 & 15.40 & 2619.22 & 2.13 & 0.7 \\
\hline Z2-4 & 200 & 109 & 64 & 0.5 & 5678 & 0.17437 & 0.49920 & 0.21 & 12.2014 & 0.23 & 0.17727 & 0.08 & 0.93 & 2610.35 & 5.49 & 2620.01 & 5.90 & 2627.49 & 2.12 & 0.7 \\
\hline Z2-5 & 210 & 107 & 64 & 0.1 & 35032 & 0.18612 & 0.50672 & 0.22 & 12.5701 & 0.23 & 0.17992 & 0.07 & 0.95 & 2642.60 & 5.74 & 2647.99 & 6.03 & 2652.11 & 1.83 & 0.4 \\
\hline Z2-6 & 210 & 189 & 116 & 0.5 & 10174 & 0.19243 & 0.51340 & 0.21 & 12.9209 & 0.21 & 0.18253 & 0.06 & 0.96 & 2671.13 & 5.48 & 2673.90 & 5.74 & 2675.99 & 1.69 & 0.2 \\
\hline Z2-7 & 240 & 369 & 231 & 1.4 & 7553 & 0.19373 & 0.52272 & 0.51 & 13.4341 & 0.52 & 0.18640 & 0.12 & 0.97 & 2710.73 & 13.81 & 2710.66 & 14.20 & 2710.62 & 3.32 & 0.0 \\
\hline Z3-1 & 150 & 44 & 27 & 0.4 & 2656 & 0.34008 & 0.46679 & 0.23 & 10.6349 & 0.25 & 0.16524 & 0.09 & 0.94 & 2469.47 & 5.80 & 2491.76 & 6.22 & 2509.98 & 2.22 & 1.6 \\
\hline Z3-2 & 190 & 113 & 70 & 0.7 & 4042 & 0.35807 & 0.47060 & 0.20 & 10.7264 & 0.21 & 0.16531 & 0.07 & 0.94 & 2486.19 & 4.98 & 2499.72 & 5.30 & 2510.73 & 1.77 & 1.0 \\
\hline Z3-3 & 190 & 233 & 147 & 0.1 & 70480 & 0.37799 & 0.47403 & 0.24 & 10.8413 & 0.25 & 0.16587 & 0.06 & 0.96 & 2501.21 & 5.93 & 2509.62 & 6.16 & 2516.43 & 1.63 & 0.6 \\
\hline Z3-4 & 200 & 352 & 218 & 0.6 & 15903 & 0.33439 & 0.47715 & 0.20 & 11.0074 & 0.21 & 0.16731 & 0.07 & 0.95 & 2514.84 & 5.11 & 2523.76 & 5.40 & 2530.94 & 1.70 & 0.6 \\
\hline Z3-5 & 210 & 272 & 167 & 0.2 & 37235 & 0.18277 & 0.52071 & 0.19 & 13.3477 & 0.19 & 0.18591 & 0.06 & 0.96 & 2702.19 & 5.04 & 2704.56 & 5.27 & 2706.34 & 1.53 & 0.2 \\
\hline Z3-6 & 240 & 316 & 201 & 1.9 & 4891 & 0.19422 & 0.52871 & 0.24 & 13.8604 & 0.25 & 0.19013 & 0.07 & 0.96 & 2735.99 & 6.61 & 2740.21 & 6.88 & 2743.32 & 1.88 & 0.3 \\
\hline Z4-1 & 170 & 4 & 3 & 0.3 & 480 & 0.12107 & 0.48923 & 1.00 & 11.8242 & 1.03 & 0.17529 & 0.32 & 0.95 & 2567.34 & 25.74 & 2590.58 & 26.56 & 2608.81 & 8.23 & 1.6 \\
\hline Z4-2 & 190 & 9 & 5 & 0.2 & 1043 & 0.13024 & 0.50047 & 0.56 & 12.4210 & 0.56 & 0.18000 & 0.12 & 0.98 & 2615.82 & 14.60 & 2636.77 & 14.73 & 2652.89 & 3.21 & 1.4 \\
\hline Z4-3 & 190 & 16 & 9 & 0.2 & 1898 & 0.13204 & 0.50346 & 0.38 & 12.4906 & 0.39 & 0.17993 & 0.13 & 0.95 & 2628.65 & 9.91 & 2642.02 & 10.37 & 2652.27 & 3.34 & 0.9 \\
\hline Z4-4 & 200 & 38 & 22 & 0.3 & 3525 & 0.14016 & 0.51137 & 0.23 & 12.7861 & 0.24 & 0.18134 & 0.09 & 0.94 & 2662.47 & 6.10 & 2664.02 & 6.49 & 2665.20 & 2.29 & 0.1 \\
\hline Z4-5 & 210 & 61 & 36 & 0.2 & 6911 & 0.14406 & 0.51053 & 0.23 & 12.8064 & 0.25 & 0.18193 & 0.07 & 0.96 & 2658.91 & 6.24 & 2665.52 & 6.54 & 2670.53 & 1.93 & 0.4 \\
\hline Z4-6 & 210 & 73 & 44 & 0.4 & 4906 & 0.15026 & 0.51589 & 0.24 & 13.0278 & 0.25 & 0.18315 & 0.08 & 0.95 & 2681.74 & 6.48 & 2681.67 & 6.80 & 2681.61 & 2.09 & 0.0 \\
\hline Z5-1 & 170 & 99 & 54 & 0.6 & 4715 & 0.17323 & 0.46435 & 0.18 & 11.4034 & 0.20 & 0.17811 & 0.08 & 0.92 & 2458.75 & 4.52 & 2556.70 & 5.09 & 2635.33 & 1.99 & 6.7 \\
\hline Z5-2 & 190 & 125 & 73 & 0.2 & 17613 & 0.20078 & 0.49315 & 0.21 & 12.0134 & 0.21 & 0.18022 & 0.06 & 0.96 & 2584.29 & 5.43 & 2624.04 & 5.51 & 2654.86 & 1.64 & 2.7 \\
\hline Z5-3 & 190 & 151 & 90 & 0.1 & 40190 & 0.22793 & 0.49613 & 0.21 & 12.0865 & 0.22 & 0.17669 & 0.06 & 0.96 & 2597.14 & 5.34 & 2611.14 & 5.74 & 2622.01 & 1.52 & 0.9 \\
\hline Z5-4 & 200 & 92 & 59 & 0.9 & 2693 & 0.32640 & 0.49138 & 0.21 & 11.8118 & 0.23 & 0.17434 & 0.10 & 0.91 & 2576.65 & 5.41 & 2589.60 & 5.96 & 2599.74 & 2.55 & 0.9 \\
\hline Z5-5 & 210 & 14 & 10 & 0.3 & 1380 & 0.32557 & 0.50121 & 0.36 & 12.3515 & 0.37 & 0.17873 & 0.10 & 0.96 & 2618.99 & 9.43 & 2631.50 & 9.68 & 2641.13 & 2.69 & 0.8 \\
\hline Z5-6 & 240 & 66 & 41 & 0.8 & 2473 & 0.16173 & 0.51884 & 0.21 & 13.2469 & 0.22 & 0.18518 & 0.08 & 0.93 & 2694.24 & 5.60 & 2697.41 & 6.03 & 2699.78 & 2.24 & 0.2 \\
\hline Z6-1 & 170 & 10 & 6 & 0.5 & 463 & 0.04737 & 0.44768 & 0.51 & 9.9514 & 0.52 & 0.16122 & 0.14 & 0.96 & 2384.91 & 12.23 & 2430.29 & 12.65 & 2468.51 & 3.49 & 3.4 \\
\hline Z6-2 & 190 & 17 & 8 & 0.2 & 2587 & 0.05344 & 0.45798 & 0.36 & 10.3980 & 0.37 & 0.16467 & 0.10 & 0.97 & 2430.61 & 8.84 & 2470.87 & 9.17 & 2504.15 & 2.43 & 2.9 \\
\hline Z6-3 & 190 & 28 & 14 & 0.2 & 4181 & 0.07534 & 0.47119 & 0.40 & 10.6848 & 0.42 & 0.16446 & 0.11 & 0.97 & 2488.78 & 10.02 & 2496.10 & 10.36 & 2502.07 & 2.68 & 0.5 \\
\hline Z6-4 & 200 & 51 & 27 & 0.3 & 4600 & 0.10561 & 0.47746 & 0.20 & 10.9522 & 0.21 & 0.16636 & 0.07 & 0.94 & 2516.21 & 5.01 & 2519.08 & 5.31 & 2521.39 & 1.79 & 0.2 \\
\hline Z6-5 & 210 & 84 & 46 & 0.2 & 10388 & 0.13851 & 0.48603 & 0.20 & 11.3985 & 0.21 & 0.17009 & 0.06 & 0.95 & 2553.46 & 5.13 & 2556.30 & 5.39 & 2558.56 & 1.65 & 0.2 \\
\hline Z6-6 & 210 & 141 & 83 & 0.3 & 13273 & 0.15858 & 0.50972 & 0.23 & 12.7800 & 0.24 & 0.18184 & 0.06 & 0.97 & 2655.45 & 6.05 & 2663.57 & 6.27 & 2669.75 & 1.57 & 0.5 \\
\hline Z6-7 & 240 & 90 & 54 & 0.4 & 6217 & 0.16117 & 0.51726 & 0.25 & 13.0907 & 0.26 & 0.18355 & 0.07 & 0.97 & 2687.54 & 6.68 & 2686.21 & 6.88 & 2685.21 & 1.80 & -0.1 \\
\hline
\end{tabular}

All grains chemically abraded at $150{ }^{\circ} \mathrm{C}$ prior to first partial dissolution. 240 indicates $48 \mathrm{~h}$ at $240{ }^{\circ} \mathrm{C}$.

Quoted errors are $2 \mathrm{~s}$ (\% for atomic ratios, absolute for ages).
$\mathrm{a}$ Measured ratio corrected for fractionation and spike $\mathrm{Pb}$.

b Corrected for fractionation, spike, laboratory blank $\mathrm{Pb}$ and $\mathrm{U}$, and initial common Pb estimated from Stacey and Kramers, 1975 . Laboratory blank $\mathrm{Pb}$ composition is ${ }^{206} \mathrm{~Pb} /{ }^{204} \mathrm{~Pb}:{ }^{207} \mathrm{~Pb} /{ }^{204} \mathrm{~Pb}:{ }^{208} \mathrm{~Pb} /{ }^{204} \mathrm{~Pb}=18.19: 15.58: 38.50$.

c ${ }^{207} \mathrm{~Pb} /{ }^{235} \mathrm{U}-{ }^{206} \mathrm{~Pb} /{ }^{238} \mathrm{U}$ error correlation coefficient calculated following Ludwig (2003). 
A

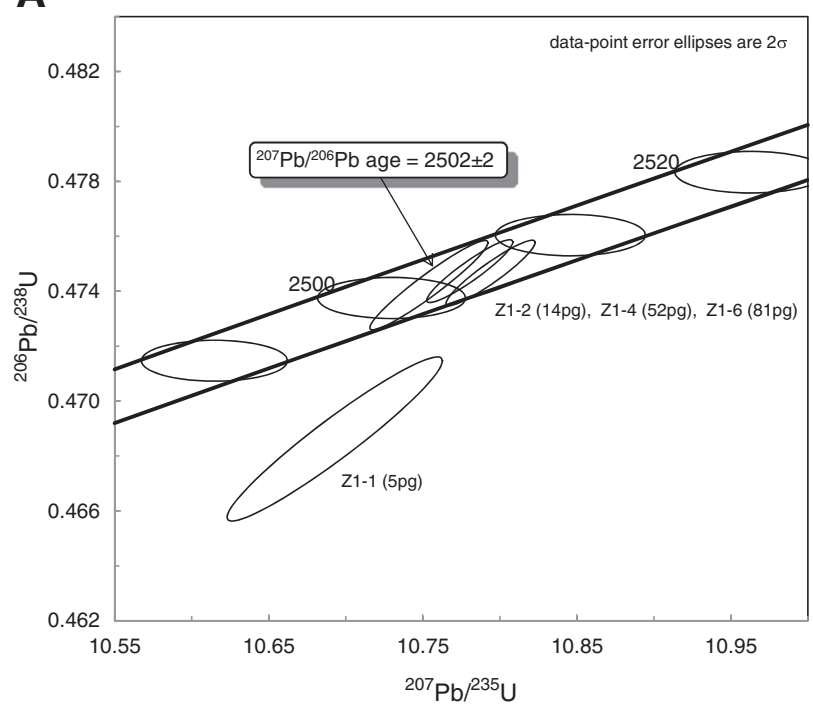

C

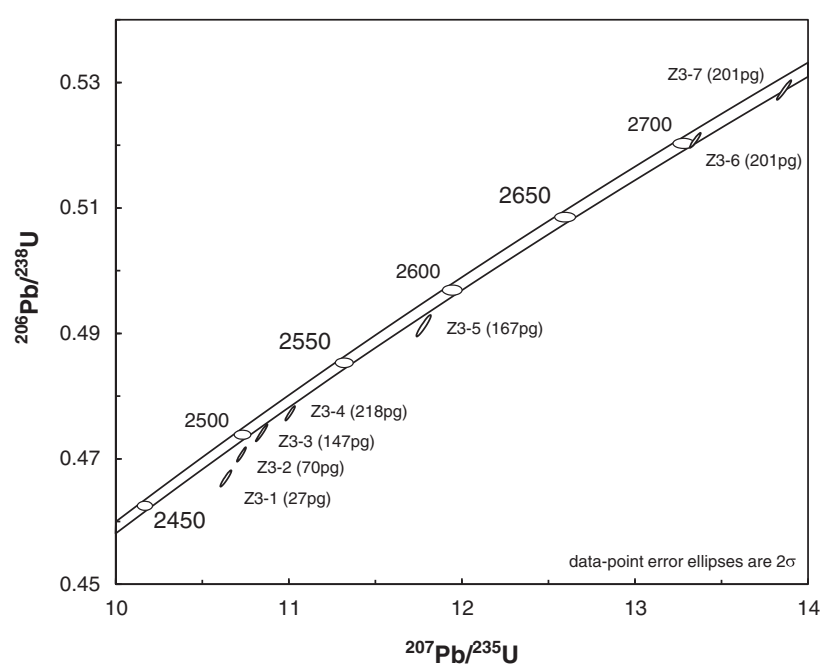

E

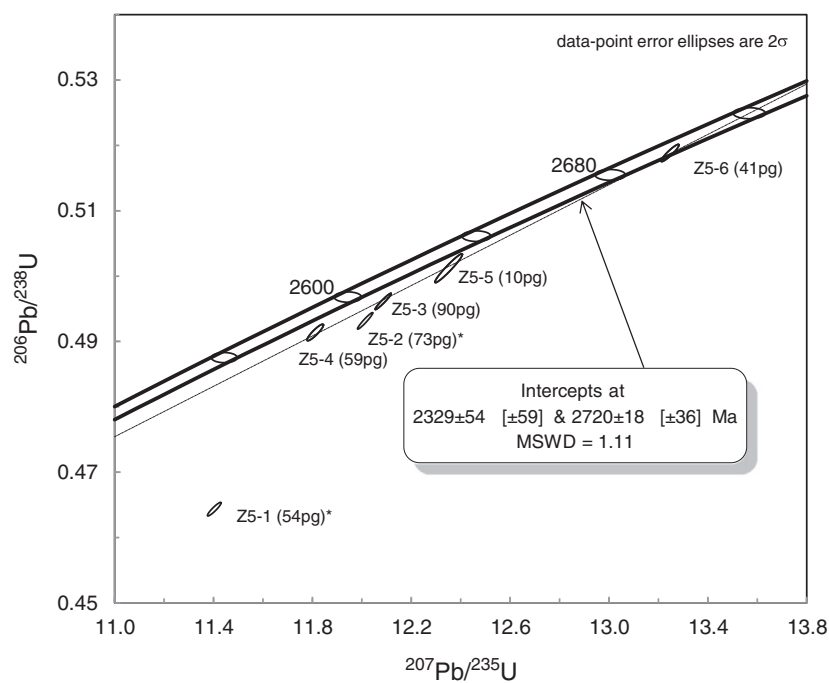

B

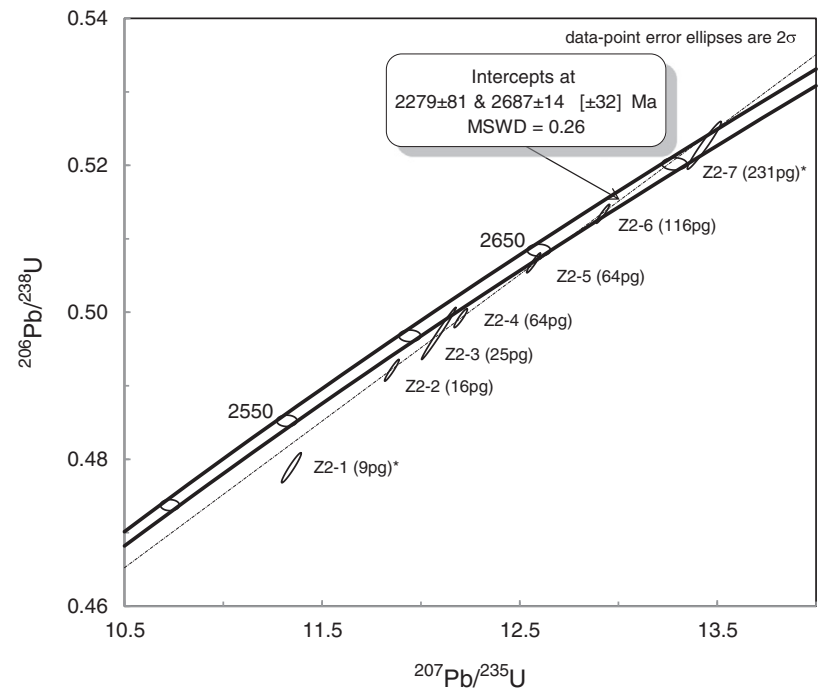

D

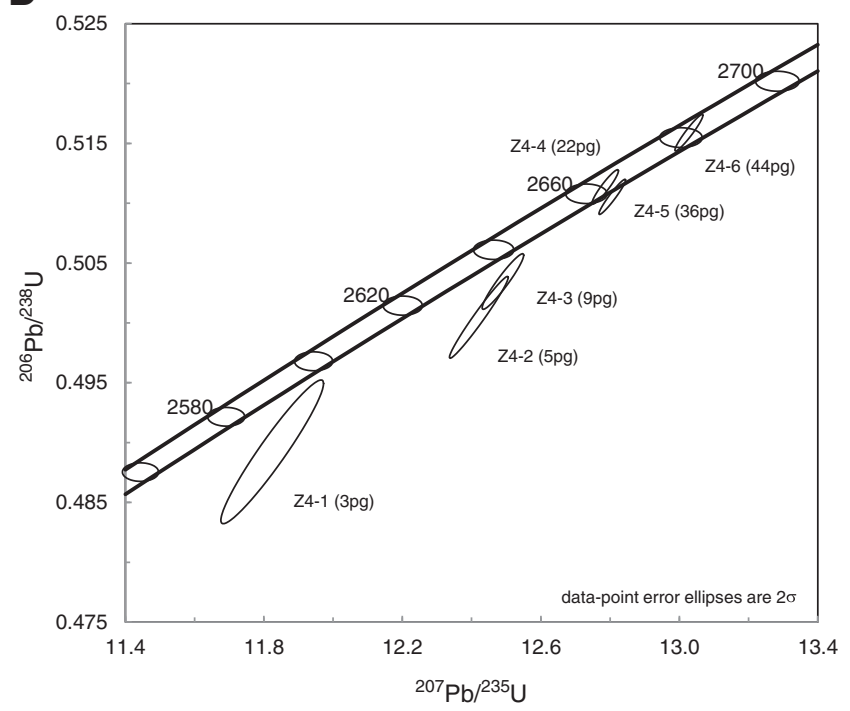

F

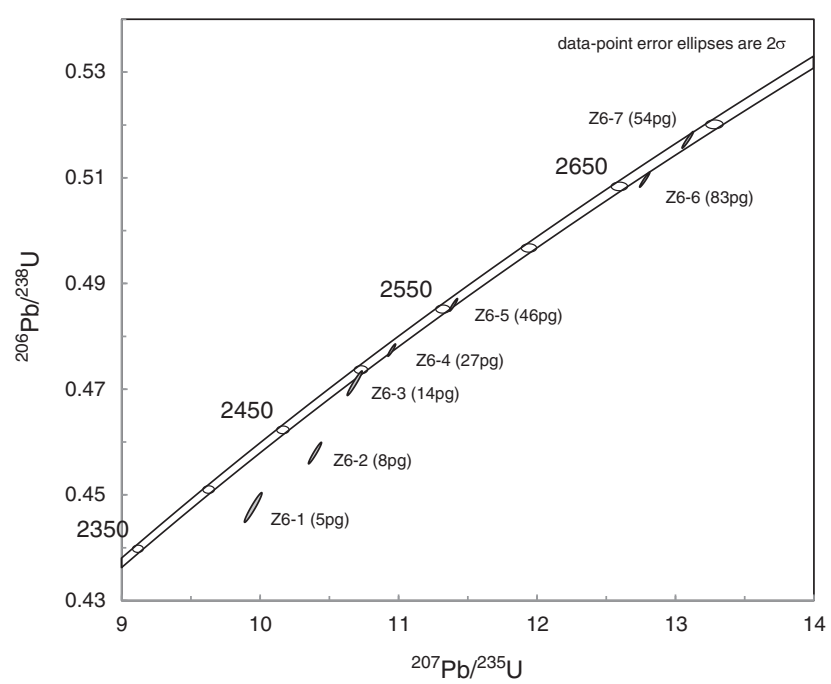

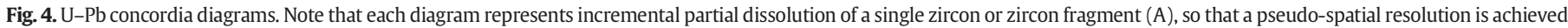
with high-precision ID-TIMS data. Analyses marked “*” are not used in the construction of intercept ages. 


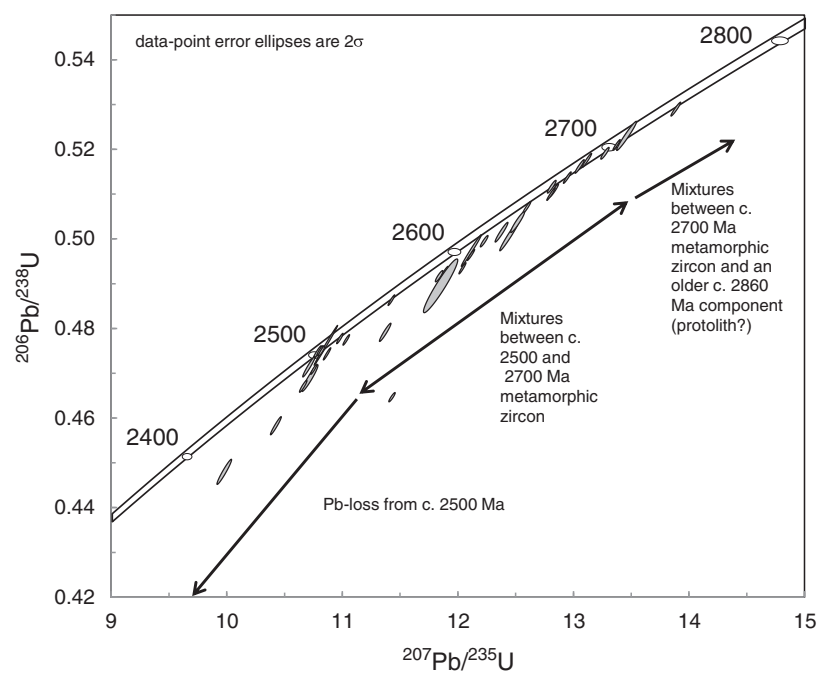

Fig. 5. Compilation U-Pb concordia diagram for all data presented in this study. Note arrows indicating interpretation as (i) Pb-loss from c. 2500 Ma, (ii) mixtures of c. 2500 and $2700 \mathrm{Ma}$ metamorphic zircon and (iii) mixtures of c. 2700 Ma zircon and a c. 2860 Ma igneous protolith.

All U-Pb analyses from Z4 are less than $2 \%$ discordant, with the level of discordance decreasing for the first 4 partial dissolution steps giving apparent ages increasing from c. 2609 to $2665 \mathrm{Ma}$ (Fig. 4D). The last partial dissolution step $\left(210{ }^{\circ} \mathrm{C}\right)$ records a slight increase in discordance and an older apparent age of $2671 \pm 2 \mathrm{Ma}$, whereas the complete dissolution step yields a concordant age of $2682 \pm 2 \mathrm{Ma}$. These data are not straightforward to interpret and may reflect multiple episodes of partial resetting and Pb-loss from a c. $2700 \mathrm{Ma}$ zircon. Interestingly, Z4-1, -2, -3, -5 and -6 define a discordia with an upper intercept age of $2683 \pm 17 \mathrm{Ma}$ and a lower intercept of $1868 \pm 160 \mathrm{Ma}$. The lower intercept age is within error of Laxfordian events known to have affected the region.

The two lowest temperature partial dissolutions (170 and $190{ }^{\circ} \mathrm{C}$ ) for zircon Z5 are 6.7 and 2.7\% discordant with apparent ages of c. 2635 and c. 2655 Ma respectively (Fig. 4E). Although the following two partial dissolutions ( 190 and $200{ }^{\circ} \mathrm{C}$ ) are less discordant, they give younger apparent ages of $2622 \pm 2$ and $2600 \pm 3$ Ma with a corresponding dramatic decrease in $\mathrm{U}$ concentration from 125 to $92 \mathrm{pg}$ between the first $190^{\circ} \mathrm{C}$ and $200{ }^{\circ} \mathrm{C}$ steps. This may be due to selective partial dissolution of an older, higher U component. Disregarding the first two partial dissolutions, which show the most severe Pb-loss, the remaining fractions define a discordia with an upper intercept of $2720 \pm 18 \mathrm{Ma}$ (MSWD $=1.11$ ). Zircon fraction Z5-6, corresponding to the final dissolution at $240{ }^{\circ} \mathrm{C}$, is the most concordant giving an age of $2700 \pm 1 \mathrm{Ma}$. U-Pb data from this zircon are interpreted as representing a c. $2700 \mathrm{Ma}$ zircon with either ancient Pb-loss a minor younger component $<2600 \mathrm{Ma}$.

Seven separate analyses were conducted of zircon Z6, the first three of which define a Pb-loss trajectory, with decreasing discordance, to c. $2500 \mathrm{Ma}$. The remaining four analyses of Z6 define a mixing trajectory between c. 2500 and c. $2700 \mathrm{Ma}$, but with a relatively high MSWD indicating some scatter in the data (Fig. 4F). This is interpreted as representing a three component mixture between c. 2500 and $\mathrm{c}$. 2700 Ma with some ancient Pb-loss.

Plotting all data for the sample (Fig. 5) is informative and indicates (1) Pb-loss from a c. 2500 Ma component, (2) a mixture of c. 2500 and $2700 \mathrm{Ma}$ components and variable Pb-loss and (3) an older component of c. 2860 Ma determined as an upper intercept age from the four oldest analyses.

\section{Geological implications}

Our dataset helps to resolve several ongoing debates regarding the Lewisian Gneiss Complex. One model initially proposed by Friend and
Kinny (2001) and later modified by Kinny et al. (2005) and Love et al. (2010) states that up to eleven distinct terranes, most of which are separated by shear zones, exist in this relatively small geographic region. This argument is primarily based on the interpreted protolith and metamorphic ages in various fault bounded blocks. The existence of c. 3030-2960 Ma zircon ages in the Assynt block TTGs have been interpreted by some as protolith ages (e.g. Friend and Kinny, 1995; Kinny et al., 2005). Whitehouse and Kemp (2010) however, who performed $\mathrm{U}-\mathrm{Pb}$ and $\mathrm{Hf}$ isotope analyses of zircon separated from granulite gneisses in this region, favour protolith ages in the 2950-2850 Ma range and demonstrated that crustal precursors were derived from the mantle at 3200-3000 Ma. Goodenough et al. (2013) report a protolith age of c. $2840 \mathrm{Ma}$ from a folded micro-granite, also in the Assynt block. An upper intercept age of c. 2860 Ma determined from our four oldest analyses supports the notion that ages of 3030-2960 previously determined from the central region most likely represent inherited ages. If the oldest protolith ages across the central block are indeed $<2960 \mathrm{Ma}$, this would not support separation of distinct Gruinard and Assynt terranes. Furthermore, this begins to question the validity of a multi-terrane model for the mainland Lewisian Gneiss Complex as a whole, as protolith ages of c. 2860-2840 Ma are found across the region.

One striking feature of our multi-step partial dissolution zircon dataset is the unequivocal presence of both c. $2500 \mathrm{Ma}$ and c. $2700 \mathrm{Ma}$ components, sometimes evident within single grains. Importantly, if the granulite event in the Assynt block is taken as c. 2490-2480 Ma (Love et al., 2010; Whitehouse and Kemp, 2010), this would signify a difference in timing of granulite events affecting the Assynt and Gruinard blocks. Previously, the apparent absence of a c. 2700 Ma age from the Assynt block was one of the key criteria for its designation as separate terrane (Kinny et al., 2005). Our new, high-precision data calls into question the assertion that there is any significant difference in the timing of a high-grade metamorphic event between the Assynt and Gruinard blocks. When the analytical precision of published ion probe $\mathrm{U}-\mathrm{Pb}$ zircon datasets from granulite rocks of the Assynt block are examined, it is not surprising that several authors have not recognised this c. 2700 Ma event. This may be attributed to the ion-probe data overlapping with concordia and the final high-grade metamorphic event effecting these rocks being 200 m.y. later $(<10 \%$ difference at this timescale). Although our dataset does document the presence of these two metamorphic ages it is not a trivial matter to assign individual ages to a particular event recognised on a macro-scale in the rock record. This is partly due to the restricted composition and hence mineralogy of the gneiss analysed. Field evidence indicates a major Inverian structure, the Canisp Shear Zone, is nearby and that this structure overprints the Badcallian event. Therefore, when both field evidence and micro-textural information from CL images are combined with geochronology, we interpret the presence of both c. 2700 and c. $2500 \mathrm{Ma}$ ages as representing the Badcallian and Inverian events respectively. Interestingly, a Pb-loss lower intercept age of c. $1870 \mathrm{Ma}$ from one set of our zircon analyses overlaps with known Laxfordian ages from the region. This emphasises that the effects of the Laxfordian event are widespread across the complex, even when there are no obvious signs of this at outcrop level.

\section{Conclusions}

Representative zircon separated from a partially retrogressed granulite tonalite gneiss from the Assynt block of the Lewisian Gneiss Complex have been treated by thermal annealing, sequential partial dissolution and ID-TIMS analysis. By relating TIMS analyses to representative $\mathrm{CL}$ images of zircon from the same sample, ${ }^{207} \mathrm{~Pb} /{ }^{206} \mathrm{~Pb}$ ages may be equated to two episodes of high-grade metamorphism and an older component, interpreted as the protolith age. U-Pb zircon data show evidence for ancient Pb-loss, with at least one such episode occurring in the Paleoproterozoic. This approach of integrating annealing and sequential partial dissolution with ID-TIMS gives a pseudo-spatial 
resolution, whereby it is possible to resolve between age domains in single grains, or pooled data from several single grain analyses, even when there is $\ll 10 \%$ age difference between such domains. In this instance, an analytical precision of c. $0.1 \% 2 \sigma$ (includes decay constant error and error in spike calibration) can be achieved on individual, ${ }^{207} \mathrm{~Pb} /{ }^{206} \mathrm{~Pb}$ ages. This utility is particularly applicable to the Archean rock record where it has proven impossible to distinguish between ages using conventional microbeam techniques. This method could also potentially be applied to younger parts of the geological timescale to resolve multiple ages from single grains (e.g. resolving magma chamber residence).

Relict eclogite mineral assemblages contained within maficultramafic rocks the study region (Sajeev et al., 2013) are intimately associated with granulite tonalite gneisses. The relative timing of formation of these two lithologies is unclear. Either: (1) both were formed in the same event and subducted to depths of $>70 \mathrm{~km}$, but with the tonalite gneisses being fully retrogressed at granulite facies upon exhumation, or (2) the mafic-ultramafic rocks were subducted to eclogite conditions and later intruded in granulite facies conditions by the tonalite gneiss protolith. Either scenario is plausible and demonstrates that an age of c. $2700 \mathrm{Ma}$, which we equate with the granulite Badcallian event, places a minimum age constraint on what is currently known to be the highest crustal pressures reported from Archean rocks.

Our new data do not support a terrane boundary between the Assynt and Gruinard blocks but instead give credence to simpler models, including one proposed by Park (2005) which invokes only two separate terranes on the mainland complex. This forms part of a growing body of evidence which indicates a number of key magmatic, metamorphic and deformation events are found across the complex as a whole (Goodenough et al., 2010; Whitehouse and Kemp, 2010; Goodenough et al., 2013). Collectively, and in broad terms, tectono-thermal and magmatic events forming or affecting the Lewisian Gneiss Complex may be interpreted as: (1) formation of Archean crust and an early subduction zone giving rise to the eclogite and granulite assemblages within the gneisses, (2) Paleoproterozoic rifting and fragmentation of an Archean craton, as documented by the Scourie dykes and (3) reassembly involving subduction, development of magmatic arcs and formation of accretionary complexes (e.g. Loch Maree Group) culminating in creation of a stable Paleoproterozoic continental crust.

\section{Acknowledgements}

This research was funded through a BGS-NIGL grant to the authors. Thanks to Mr Neil Boulton and Mr Aaran Sumner at NIGL for technical support with TIMS work and to Mr Grenville Turner at the BGS for assistance with CL images. Thanks also to Ms Elaine Cullen at TCD for drafting Fig. 1. Jim Mattinson and Fernando Corfu are thanked for their thorough and constructive review. M. Santosh is thanked for his efficient editorial handling.

\section{References}

Baba, S., 2002. Tectono-metamorphic events in the North Atlantic Region in the Palaeoproterozoic from the view point of high-grade metamorphic rocks in the Lewisian Complex, South Harris, NW Scotland. Gondwana Research 5, 757-770.

Bagas, L., Næraa, T., Kolb, J., Reno, B.L., Fiorentini, M.L., 2013. Partial melting of the Archaean Thrym Complex of southeastern Greenland. Lithos 160-161, 164-182.

Bergh, S.G., Kullerud, K., Corfu, F., Armitage, P.E.B., Davidsen, B., Johansen, H.W., Pettersen, T., Knudsen, S., 2007. Low-grade sedimentary rocks on Vanna, North Norway: a new occurrence of a Paleoproterozoic $(2.4-2.2 \mathrm{Ga})$ cover succession in northern Fennoscandia. Norsk Geologisk Tidsskrift 87, 301-318.

Borradaile, G.J., Geneviciene, I., 2008. Late Proterozoic reconstructions of North-West Scotland and Central Canada: magnetic fabrics, paleomagnetism and tectonics. Journal of Structural Geology 30, 1466-1488.

Cartwright, I., Barnicoat, A.C., 1987. Petrology of Scourian supracrustal rocks and orthogneisses from Stoer, NW Scotland: Implications for the geological evolution of the Lewisian complex. Geological Society Special Publication 27, 93-107.

Chattopadhyay, A., Holdsworth, R.E., McCaffrey, K.J.W., Wilson, R.W., 2010. Recording and analyzing geospatially accurate structural data through 'digital mapping' technique: a case study from the Canisp Shear Zone, NW Scotland. Journal of the Geological Society of India 75, 43-59.

Cohen, A.S., O'Nions, R.K., O'Hara, M.J., 1991. Chronology and mechanism of depletion in Lewisian granulites. Contributions to Mineralogy and Petrology 106, 142-153.

Cooper, M.R., Crowley, Q.G., Hollis, S.P., Noble, S.R., Roberts, S., Chew, D., Earls, G. Herrington, R., Merriman, R.J., 2011. Age constraints and geochemistry of the Ordovician Tyrone igneous complex, Northern Ireland: Implications for the Grampian orogeny. Journal of the Geological Society 168, 837-850.

Corfu, F., 2000. Extraction of $\mathrm{Pb}$ with artificially too-old ages during stepwise dissolution experiments on Archean zircon. Lithos 53, 279-291.

Corfu, F., Noble, S.R., 1992. Genesis of the southern Abitibi greenstone belt, Superior Province, Canada: evidence from zircon $\mathrm{Hf}$ isotope analyses using a single filament technique. Geochimica et Cosmochimica Acta 56, 2081-2097.

Corfu, F., Heaman, L.M., Rogers, G., 1994. Polymetamorphic evolution of the Lewisian complex, NW Scotland, as recorded by U-Pb isotopic compositions of zircon, titanite and rutile. Contributions to Mineralogy and Petrology 117, 215-228.

Corfu, F., Crane, A., Moser, D., Rogers, G., 1998. U-Pb zircon systematics at Gruinard Bay, northwest Scotland: implications for the early orogenic evolution of the Lewisian complex. Contributions to Mineralogy and Petrology 133, 329-345.

Coward, M.P., 1990. Shear zones at the Laxford front, NW Scotland and their significance in the interpretation of lower crustal structure. Journal of the Geological Society of London 147, 279-286.

Coward, M.P., Park, R.G., 1987. The role of mid-crustal shear zones in the Early Proterozoic evolution of the Lewisian. Geological Society Special Publication 27, 127-138.

Evans, C.R., 1965. Geochronology of the Lewisian basement near Lochinver, Sutherland. Nature 207, 54-56.

Flowerdew, M.J., Chew, D.M., Daly, J.S., Millar, I.L., 2009. Hidden Archaean and Paleoproterozoic crust in NW Ireland? Evidence from zircon Hf isotopic data from granitoid intrusions. Geological Magazine 146, 903-916.

Friend, C.R.L., Kinny, P.D., 1995. New evidence for protolith ages of Lewisian granulites northwest Scotland. Geology 23, 1027-1030.

Friend, C.R.L., Kinny, P.D., 2001. A reappraisal of the Lewisian Gneiss Complex: geochronological evidence for its tectonic assembly from disparate terranes in the Proterozoic. Contributions to Mineralogy and Petrology 142, 198-218.

Gerstenberger, H., Haase, G., 1997. A highly effective emitter substance for mass spectrometric $\mathrm{Pb}$ isotope ratio determinations. Chemical Geology 136, 309-312.

Giletti, B.J., Moorbath, S., Lambert, R.S.J., 1961. A geochronological study of the metamorphic complexes of the Scottish highlands. Quarterly Journal of the Geological Society of London 117, 233-264.

Goodenough, K.M., Park, R.G., Krabbendam, M., Myers, J.S., Wheeler, J., Loughlin, S.C., Crowley, Q.G., Friend, C.R.L., Beach, A., Kinny, P.D., Graham, R.H., 2010. The Laxford shear zone: an end-Archaean terrane boundary? Geological Society Special Publication $335,103-120$.

Goodenough, K.M., Crowley, Q.G., Krabbendam, M., Parry, S.F., 2013. New U-Pb age constraints for the Laxford Shear Zone, NW Scotland: evidence for tectono-magmatic processes associated with the formation of a Paleoproterozoic supercontinent. Precambrian Research 233, 1-19.

Hamilton, P.J., Evensen, N.M., O'Nions, R.K., Tarney, J., 1979. Sm-Nd systematics of Lewisian gneisses: implications for the origin of granulites. Nature $277,25-28$.

Heaman, L., Tarney, J., 1989. U-Pb baddeleyite ages for the Scourie dyke swarm, Scotland: evidence for two distinct intrusion events. Nature 340, 705-708.

Hitchen, K., 2004. The geology of the UK Hatton-Rockall margin. Marine and Petroleum Geology 21, 993-1012.

Jiang, N., Guo, J., Chang, G., 2013. Nature and evolution of the lower crust in the eastern North China craton: a review. Earth-Science Reviews 122, 1-9.

Johnson, T.E., Fischer, S., White, R.W., 2013. Field and petrographic evidence for partial melting of TTG gneisses from the central region of the mainland Lewisian complex, NW Scotland. Journal of the Geological Society 170, 319-326.

Kinny, P.D., Friend, C.R.L., 1997. U-Pb isotopic evidence for the accretion of different crustal blocks to form the Lewisian Complex of northwest Scotland. Contributions to Mineralogy and Petrology 129, 326-340.

Kinny, P.D., Friend, C.R.L., Love, G.J., 2005. Proposal for a terrane-based nomenclature for the Lewisian Gneiss Complex of NW Scotland. Journal of the Geological Society 162 175-186.

Kolb, J., Thrane, K., Bagas, L., 2013. Field relationship of high-grade Neo- to Mesoarchaean rocks of South-East Greenland: Tectonometamorphic and magmatic evolution. Gondwana Research 23, 471-492.

Krogh, T.E., 1973. A low-contamination method for hydrothermal decomposition of zircon and extraction of $\mathrm{U}$ and $\mathrm{Pb}$ for isotopic age determinations. Geochimica et Cosmochimica Acta 37, 485-494.

Krogh, T.E., 1982. Improved accuracy of U-Pb zircon ages by the creation of more concordant systems using an air abrasion technique. Geochimica et Cosmochimica Acta 46 637-649.

Kryza, R., Crowley, Q.G., Larionov, A., Pin, C., Oberc-Dziedzic, T., Mochnacka, K., 2012 Chemical abrasion applied to SHRIMP zircon geochronology: an example from the Variscan Karkonosze Granite (Sudetes, SW Poland). Gondwana Research 21, 757-767.

Love, G.J. Kinny, P.D., Friend, C.R.L, 2004. Timing of magmatism and metamorphism in the Gruinard Bay area of the Lewisian Gneiss Complex: Comparisons with the Assynt Terrane and implications for terrane accretion. Contributions to Mineralogy and Petrology 146, 620-636.

Love, G.J., Friend, C.R.L., Kinny, P.D., 2010. Paleoproterozoic terrane assembly in the Lewisian Gneiss Complex on the Scottish mainland, south of Gruinard Bay: SHRIMP U-Pb zircon evidence. Precambrian Research 183, 89-111.

Ludwig, K.R., 1980. Calculation of uncertainties of U-Pb isotope data. Earth and Planetary Science Letters 46, 212-220. 
Ludwig, K.R., 2003. Isoplot 3.00: A geochronological toolkit for Microsoft Excel. Berkeley Geochronology Centre Special Publication 4, 0-71.

MacDonald, J.M., Wheeler, J., Harley, S.L., Mariani, E., Goodenough, K.M., Crowley, Q., Tatham, D., 2013. Lattice distortion in a zircon population and its effects on trace element mobility and $\mathrm{U}-\mathrm{Th}-\mathrm{Pb}$ isotope systematics: examples from the Lewisian Gneiss Complex, northwest Scotland. Contributions to Mineralogy and Petrology 166, 21-41.

Mason, A.J., 2012. Major early thrusting as a control on the palaeoproterozoic evolution of the Lewisian complex: Evidence from the outer Hebrides, NW Scotland. Journal of the Geological Society 169, 201-212.

Mason, A.J., Brewer, T.S., 2005. A re-evaluation of a Laxfordian terrane boundary in the Lewisian Complex of South Harris, NW Scotland. Journal of the Geological Society 162, 401-407.

Mattinson, J.M., 1994. A study of complex discordance in zircon using step-wise dissolution techniques. Contributions to Mineralogy and Petrology 116, 117-129.

Mattinson, J.M., 2005. Zircon U-Pb chemical abrasion ("CA-TIMS") method: Combined annealing and multi-step partial dissolution analysis for improved precision and accuracy of zircon ages. Chemical Geology 220, 47-66.

Mattinson, J.M., Graubard, C.M., Parkinson, D.L., McClelland, W.C., 1996. U-Pb reverse discordance in zircons: the role of fine-scale oscillatory zoning and submicron transport of Pb. In: Basu, A.R., Hart, S.R. (Eds.), Earth Processes: Reading the Isotopic Code. Geophysical Monograph Series, vol. 95. American Geophysical Union, pp. 355-370.

McClelland, W.C., Mattinson, J.M., 1996. Resolving high precision U-Pb ages from Tertiary plutons with complex zircon systematics. Geochimica et Cosmochimica Acta 60, 3955-3965.

Moorbath, S., Welke, H., Gale, N.H., 1969. The significance of lead isotope studies in ancient, high-grade metamorphic basement complexes, as exemplified by the Lewisian rocks of Northwest Scotland. Earth and Planetary Science Letters 6, 245-256.

Mundil, R., Ludwig, K.R., Metcalfe, I., Renne, P.R., 2004. Age and timing of the Permian mass extinctions: $\mathrm{U} / \mathrm{Pb}$ dating of closed-system zircons. Science 305, 1760-1763.

Nilsson, M.K.M., Klausen, M.B., Söderlund, U., Ernst, R.E., 2013. Precise U-Pb ages and geochemistry of Palaeoproterozoic mafic dykes from southern West Greenland: linking the North Atlantic and the Dharwar cratons. Lithos 174, 255-270.

Noble, S.R., Schweiters, J., Condon, D.J., Crowley, Q.G., Quaas, N., Parrish, R.R., 2006 TIMS characterization of new generation of secondary electron multiplier. EOS Transactions of the American Geophysical Union, 87 (Fall Meeting Supplement Abstract).

O'Driscoll, B., Day, J.M.D., Daly, J.S., Walker, R.J., McDonough, W.F., 2009. Rheniumosmium isotopes and platinum-group elements in the Rum Layered Suite, Scotland: Implications for $\mathrm{Cr}$-spinel seam formation and the composition of the Iceland mantle anomaly. Earth and Planetary Science Letters 286, 41-51.

O'Hara, M.J., 1977. Thermal history of excavation of Archaean gneisses from the base of the continental crust. Journal of the Geological Society 134, 185-200.

Park, R.G., 1966. Nature and origin of Lewisian basic rocks of Gairloch, Ross-shire. Scottish Journal of Geology 2, 179-199.

Park, R.G., 1970. Observations on Lewisian chronology. Scottish Journal of Geology 6, 379-399.

Park, R.G., 2005. The Lewisian terrane model: a review. Scottish Journal of Geology 41 $105-118$.

Park, R.G., Tarney, J., Connelly, J.N., 2001. The Loch Maree Group: Paleoproterozoic subduction-accretion complex in the Lewisian of NW Scotland. Precambrian Research 105, 205-226.

Peach, B.N., Horne, J., Gunn, W., Clough, C.T., Hinxman, L.W., Teall, J.J.H., 1907. The geological structure of the North-West Highlands of Scotland. Memoir of the Geological Survey of Great BritainHMSO, Glasgow.

Pidgeon, R.T., Aftalion, M., 1972. The geochronological significance of discordant U-Pb ages of oval-shaped zircons from a Lewisian gneiss from Harris, Outer Hebrides. Earth and Planetary Science Letters 17, 269-274.
Rekha, S., Viswanath, T.A., Bhattacharya, A., Prabhakar, N., 2013. Meso/Neoarchean crustal domains along the north Konkan coast, western India: the Western Dharwar Craton and the Antongil-Masora Block (NE Madagascar) connection. Precambrian Research 233, 316-336.

Rollinson, H., 2012. Geochemical constraints on the composition of Archaean lower continental crust: partial melting in the Lewisian granulites. Earth and Planetary Science Letters 351-352, 1-12.

Rollinson, H.R., Windley, B.F., 1980. An archaean granulite-grade tonalite-trondhjemitegranite suite from Scourie, NW Scotland: Geochemistry and origin. Contributions to Mineralogy and Petrology 72, 265-281.

Sajeev, K., Windley, B.F., Hegner, E., Komiya, T., 2013. High-temperature, high-pressure granulites (retrogressed eclogites) in the central region of the Lewisian, NW Scotland: crustal-scale subduction in the Neoarchaean. Gondwana Research 23, 526-538.

Santosh, M. Shaji, E., Tsunogae, T. Ram Mohan, M., Satyanarayanan, M., Horie, K., 2013. Suprasubduction zone ophiolite from Agali hill: Petrology, zircon SHRIMP U-Pb geochronology, geochemistry and implications for Neoarchean plate tectonics in southern India. Precambrian Research 231, 301-324.

Sills, J.D., Rollinson, H.R., 1987. Metamorphic evolution of the mainland Lewisian complex (Scotland). In: Park, R.G., Tarney, J. (Eds.), Evolution of the Lewisian and Comparable Precambrian High Grade Terrains. Blackwell Scientific, pp. 81-92.

Stacey, J.S., Kramers, J.D., 1975. Approximation of terrestrial lead isotope evolution by a two-stage model. Earth and Planetary Science Letters 26, 207-221.

Sutton, J., Watson, J., 1950. The pre-Torridonian metamorphic history of the Loch Torridon and Scourie areas in the North-West Highlands, and its bearing on the chronological classification of the Lewisian. Quarterly Journal of the Geological Society of London 106, 241-307.

Tarney, J., Weaver, B.L., 1987. Mineralogy, petrology and geochemistry of the Scourie dykes: petrogenesis and crystallisation processes in dykes intruded at depth. In: Park, R.G., Tarney, J. (Eds.), Evolution of the Lewisian and Comparable Precambrian High Grade Terrains. Geological Society of London Special Publication, 27, pp. 217-233.

Todt, W.A., Büsch, W., 1981. U-Pb investigations on zircon from pre-Variscan gneisses: I. A study from the Schwartzwald, West Germany. Geochimica et Cosmochimica Acta 45, 1789-1801.

Verma, S.K., Verma, S.P., 2013. Identification of Archaean plate tectonic processes from multidimensional discrimination diagrams and probability calculations. International Geology Review 55, 225-248.

Waters, F.G., Cohen, A.S., O'Nions, R.K., O'Hara, M.J., 1990. Development of Archean lithosphere deduced from chronology and isotope chemistry of Scourie Dykes. Earth and Planetary Science Letters 97, 241-255.

Whitehouse, M.J., Bridgwater, D., 2001. Geochronological constraints on Palaeoproterozoic crustal evolution and regional correlations of the northern Outer Hebridean Lewisian Complex, Scotland. Precambrian Research 105, 227-245.

Whitehouse, M.J., Kemp, A.I.S., 2010. On the difficulty of assigning crustal residence, magmatic protolith and metamorphic ages to Lewisian granulites: constraints from combined in situ U-Pb and Lu-Hf isotopes. Geological Society Special Publication 335, 81-101.

Whitehouse, M.J., Moorbath, S., 1986. Pb-Pb systematics of Lewisian gneisses - implications for crustal differentiation. Nature 319, 488-489.

Zhu, X.K., O'Nions, R.K., Belshaw, N.S., Gibb, A.J., 1997. Lewisian crustal history from in situ SIMS mineral chronometry and related metamorphic textures. Chemical Geology 136, 205-218.

Zirkler, A., Johnson, T.E., White, R.W., Zack, T., 2012. Polymetamorphism in the mainland Lewisian complex, NW Scotland - phase equilibria and geochronological constraints from the Cnoc an t'Sidhean suite. Journal of Metamorphic Geology 30, 865-885. 